\title{
Composition and dynamics of hyporheic and surface fauna in a semi-arid stream in relation to the management of a polluted reservoir
}

\author{
N. Belaidi1 ${ }^{1}$, A. Taleb ${ }^{1}$, J. Gagneur ${ }^{*}$ \\ ${ }^{1}$ Biology Dpt, University of Tlemcen, B.P. 119, DZA-13000 Tlemcen, Algeria. \\ ${ }^{2}$ UMR LADYBIO, University Paul Sabatier, 118 route de Narbonne, F-31062 Toulouse Cedex 4, France.
}

\begin{abstract}
The mid Tafna wadi (N-W Algeria) is exposed to several man induced disturbances including urban, industrial, and agricultural effluents, and alteration of the natural flow regime. The recent installation of a reservoir upstream of the study area has strongly modified the flow regime by extending the period of low water level, and this stream section is only occasionally fed by water releases. Investigations on the hyporheos and benthos of this stream have allowed the comparison of densities, taxa richness and diversity, during three hydrological periods (natural high water, low flow and reservoir water releases), with the aim to highlight effects of the reservoir management on downstream hydrosystems. Species richness and abundance of stygobite crustaceans were low in the hyporheos. Surface water Crustaceans represented $53 \%$ of the overall fauna, with Cyclopoidae composing 50\% of the Crustaceans. The dominance of the Cyclopoidae was also observed in the hyporheos. Daphniidae were more abundant $(37 \%)$ in the benthic habitat than in the hyporheic zone. The alternation of high and low discharges appeared to affect the hyporheos more than the benthic communities. The stability concept of the hyporheic habitat does not fit with our results showing a great range of spatial (mosaic habitat) and temporal changes according to the flow regime.
\end{abstract}

Keywords : Algeria, hyporheos, flow regime, reservoir management, pollution.

\section{Introduction}

The hyporheic zone described by Orghidan (1959) constitutes an ecotone whose great structural heterogeneity (dependent mainly on the geomorphology of the river, the circulation of water in the hyporheic zone, and the exchanges between the surface water and the groundwater) has already been demonstrated (Gibert et al. 1981, Mermillod-Blondin et al. 2000, Chafiq et al. 1992, Dole-Olivier \& Marmonier 1992, Boulton \& Stanley 1995, Rouch 1995, Dole Olivier et al. 1997). These exchanges influence the nutriment dynamic (Grimm \& Fisher 1984, Claret et al. 1997) as well as the composition, distribution, and dynamics of invertebrate assemblages (Dole 1985, Marmonier \& Dole 1986). Moreover, depth, porosity and dissolved oxygen seem to be determining factors for the vertical distribution of invertebrates (Poole \& Stewart 1976, Dole

* Corresponding author : E-mail : gagneur@ cict.fr
1985, Maridet et al. 1992). The hyporheic habitat can constitute an important refuge for surface fauna during environmental disturbances such as spates and episodic acidification (Marmonier \& Dole 1986, Marmonier \& Creuzé des Châteliers 1991, Griffith \& Perry 1993). In temporary rivers of arid and semi-arid areas, it does not provide suitable refuges for benthic organisms (Gagneur \& Chaoui-Boudghane 1991, McElravy \& Resh 1991, Del Rosario \& Resh 2000) as shown in other regions (Williams 1977, Delucchi 1989, Deluchi \& Pekarsky 1989). Indeed, more adaptive and effective mechanisms are developed for survival other than using the hyporheic zone as a refuge. Thus, the drying of rivers for extended periods each year certainly influences the structure of the hyporheic fauna. However few investigations have been devoted to this question.

In the Tafna wadi (Mediterranean region), the interstitial zone has been poorly investigated compared to the surface water, mainly due to the difficulties of sampling. The substrate of the river bed (rock and coarse sediment cemented by clay) hinders sampling with 
tubes (Bendiouis 1991, Gagneur \& Chaoui-Boudghane 1991). In addition to the harsh conditions (i.e., temperature and salinity) prevailing in the middle course of the Tafna (Belaidi-Aliane 1992), the river is also exposed to strong human pressure (industries, agriculture, domestic sewage), and, more recently, to the effects of the Hammam Boughrara dam installation. The natural functioning of the wadi system is therefore deeply modified.

The aim of this paper is to describe the composition and distribution (both temporal and spatial) of the hyporheic fauna in a mid-Tafna reach, as well as to determine the role the hyporheic zone plays in the functioning of this part of the Tafna river, mainly through the relationship with the benthic fauna. We examine, through the modifications of the structure of the hyporheic assemblages, the influences of the water quality and scheduling of releases from the reservoir.

\section{Material and methods}

\section{Study area}

The Tafna (Fig. 1) is a stream draining an area of $7425 \mathrm{~km}^{2}$ in north-western Algeria. The length of the stream is approximately $170 \mathrm{~km}$. The elevation range between the source in the Tlemcen mountains and the mouth in the Mediterranean Sea is $1100 \mathrm{~m}$. The geology of the drainage basin includes dolomites and limestone upstream, and a tertiary basin downstream.

The water regime exhibits a Mediterranean climate (with sub-humid to semi-arid influences), characterized by a cold and rainy season from November through April, and a hot and dry period from May through October. The term « wadi » generally used in North Africa to name the watercourses refers to the great variations in flow. During the last decade, the Tafna wadi flowed permanently only in winter, with discharge decreasing in the spring, and ceasing in the
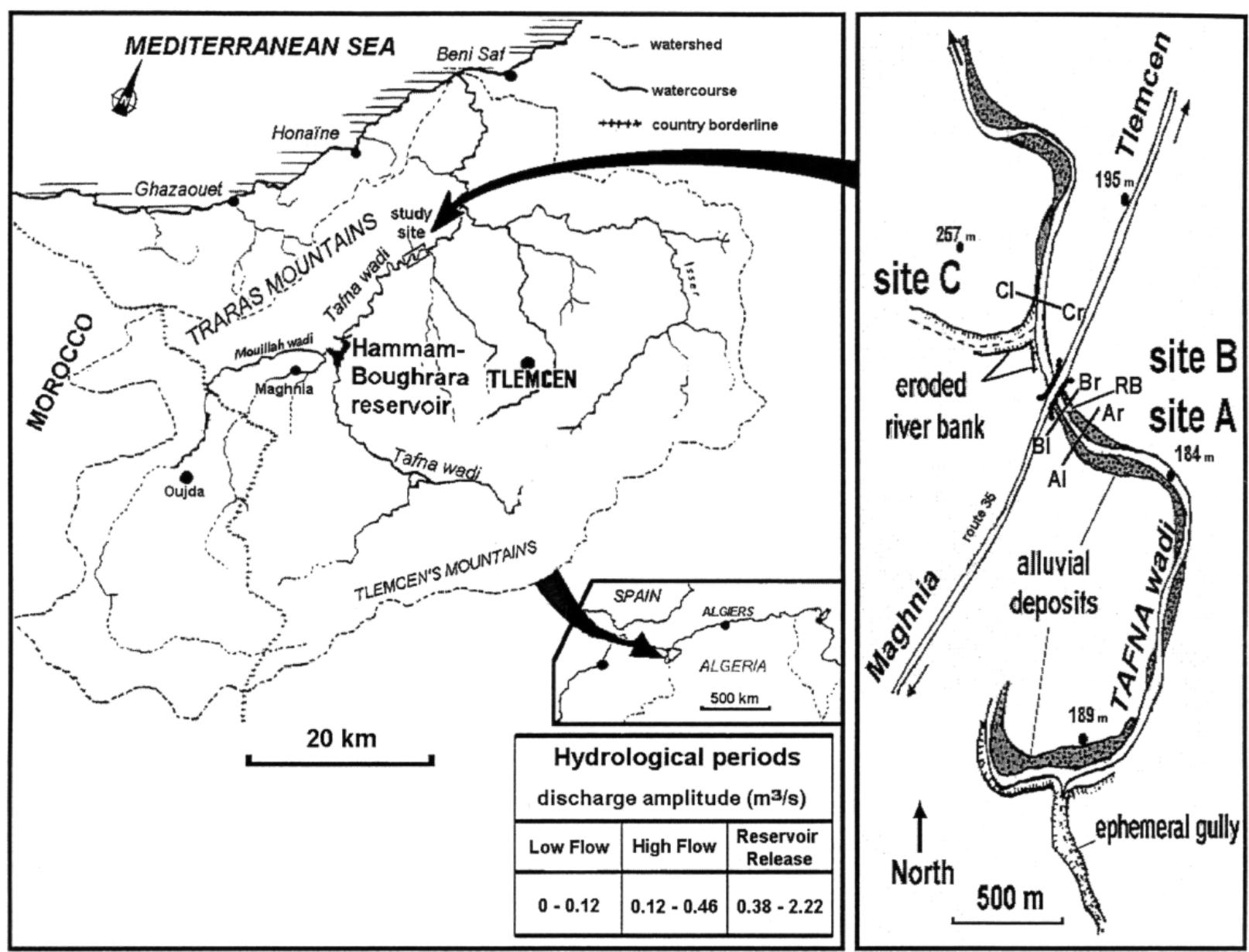

Fig.1. Location of the sampling sites within the Tafna wadi watershed. 
summer. In October, with the return of rainfall, flow returns.

The recently created Hammam-Boughrara reservoir has brought a change in the hydrological regime. This reservoir, situated about $8 \mathrm{~km}$ North-East of the Maghnia locality, at $260 \mathrm{~m}$ elevation, was achieved in 1998. It is located downstream of the confluence of the Tafna river with its principal tributary, the Mouillah wadi. This later stream receives untreated domestic sewage and industrial effluents from the Maghnia city indirectly by its tributaries, i.e., the El Abbes wadi and the Ouerdeffou wadi. The Hammam-Boughrara dam is currently operated so as to stop any flow during the period of low flow and to proceed at pulse releases accentuating the irregularity of the flow according to a non natural rhythm. The study area for this investigation is located on the mid Tafna at an elevation of 184 $\mathrm{m}, 20 \mathrm{~km}$ downstream from the Hammam-Boughrara dam.

\section{Sampling design and methods}

Interstitial fauna was collected at three sampling sites distributed along a $300 \mathrm{~m}$ stream reach : site A was located in the upstream section, site B was in the middle section, and site $\mathrm{C}$ was downstream of the study reach (Fig. 1). At each site, two piezometers were installed both one on the left and right banks. A supplementary piezometer was also installed at site B in the middle of the river channel (RB) in order to verify whether bed conditions were similar to bank conditions. Each sample consisted of 50 liters of water pum- ped using the Bou-Rouch method (Bou \& Rouch 1967, Bou 1974) from the $50 \mathrm{~cm}$ depth. Sampling was extended to the $1.50 \mathrm{~m}$ depth during dry periods. The unusual high pumped volume was set in order to compensate the fauna scarcity of this polluted site.Animals were collected using a sieve with a $150 \mu \mathrm{m}$ mesh net, and preserved in $5 \%$ formaldehyde. In the laboratory, animals were sorted and identified to the lowest possible taxonomic level (usually genus). Invertebrate density is expressed as individuals per 100 liters.

Benthic invertebrates (RS) were sampled along the reach, excepted when the river channel was dry. Three replicates $\left(1 / 10 \mathrm{~m}^{2}\right.$ each) were taken using a Surber sampler $($ mesh size $=300 \mu \mathrm{m})$. Samples of the hyporheic zone and of the benthos were taken at different hydrological periods between April 1999 and April 2001: once during the high flow period before the dam construction $(\mathrm{HF})$, twice during the dry period before the dam construction (LF), five times during dam releases $(\mathrm{R})$, and three times after dam release periods (AR).

Physicochemical measures were carried out during fauna sampling, in the field and in the laboratory. Sediment analyses were realized five times: one during drying, two during release periods, and two after release periods. Fractions were separated by sedimentation. The composition differences between periods were not significant. Therefore, average percentages are given (Table 1).

Table 1. Mean values for some physico-chemical parameters and fine sediment composition at the three hyporheic sites (A, $\mathrm{B}$ and $\mathrm{C}$ ), and in surface water (standard deviation between brackets).

\begin{tabular}{|c|c|c|c|c|c|c|c|}
\hline sites & & $\begin{array}{c}\text { A } \\
\text { ypp }\end{array}$ & & $\begin{array}{l}\text { B } \\
\text { yp }\end{array}$ & & $\begin{array}{c}\text { C } \\
\text { ayp }\end{array}$ & $\begin{array}{c}\text { Surface } \\
\text { water }\end{array}$ \\
\hline Temperature $\left({ }^{\circ} \mathrm{C}\right)$ & 20.0 & (3.3) & 19.7 & (3.5) & 20.5 & $(4.2)$ & $20.1(5.2)$ \\
\hline $\mathrm{pH}$ & 7.7 & $(0.2)$ & 7.6 & $(0.2)$ & 7.6 & $(0.3)$ & $7.8(0.4)$ \\
\hline Conductivity $(\mu \mathrm{S} / \mathrm{cm})$ & 3928 & $(1890)$ & 4749 & (2072) & 4313 & $(2136)$ & 4696 (2025) \\
\hline Dissolved oxygen $(\mathrm{mg} / \mathrm{L})$ & 1.5 & (2.8) & 1.5 & (1.9) & 1.1 & $(0.9)$ & $3.9(9.4)$ \\
\hline BOD (mg/L) & 24.2 & (51.1) & 23.7 & (55.6) & 34.3 & (56.4) & $30.6(44.4)$ \\
\hline Clay (\%) & 19.7 & & 16.6 & & 23.8 & & \\
\hline Fine silt (\%) & 11.7 & & 8.8 & & 11.9 & & \\
\hline Coarse silt (\%) & 11.9 & & 10.0 & & 12.7 & & \\
\hline Sand (\%) & 19.1 & & 21.5 & & 18.2 & & \\
\hline
\end{tabular}




\section{Statistical analysis}

In order to obtain a more normal data distribution, all the variables were log-transformed. Statistical analyses were performed using ADE4 (Thioulouse et al. 1997). The preliminary results ( 28 taxa $x 66$ samples) were analyzed by correspondence analysis (CA). The seasonal dynamic of invertebrate assemblages was determined using a between analysis, to compare abundance ranking among the three hydrological periods (high water, low water before water release, and during water release) at each site. Analysis of variance (ANOVA, MINITAB software) was used to compare densities, taxa richness, and diversity (i.e. Shannon's H') of the three sites in term of their benthic and hyporheic assemblages during the three hydrological periods. The objective was to highlight the eventual effect of the reservoir management on downstream hydrosystems.

\section{Results}

\section{Composition and distribution of the interstitial,} and benthic fauna

Despite the different sampling techniques, a comparison of community structures based on relative abundance remains pertinent. The only taxa which could have biased the results are the Cladocera Chydoridae and eventually Copepods Harpacticoidae which small forms or young instars could have passed through the Surber mesh. The benthic and hyporheic habitats (Table 2) had similar numbers of taxa (34 and 37, respectively) and the mean diversity measured by the Shannon index showed no significant difference. In term of diversity, insects formed, in both biotopes, the richest taxonomic group, followed by Crustaceans, Oligochaeta, and Nematoda. In term of abundance (Fig. 2), Crustaceans composed 53\% of the overall benthic fauna, with a dominance of the Cyclopoidae and Daphniidae (50\% and 37\%, respectively). Of all non-insect collected in the hyporheic habitat, Crustaceans were the most abundant $(75 \%)$, with in decreasing abundance: the Copepods Cyclopoidae (55\%), the Cladocera Chydoridae (23\%), and the Ostracods (13\%). Species richness and abundance of stygobite Crustaceans were low. Only two hypogean Isopod genus, Microcharon sp. and Typhlocirolana sp. (2\% of overall Crustaceans), and Copepod Harpacticoidae (3\% of overall Crustaceans) were always present during the study period. Amphipod Gammaridae and Syncarid Bathynellidae were rare and very few individuals were found in the hyporheic zone. Each of them represented less than $1 \%$ of the assemblages. Insects composed $32 \%$ of the benthic fauna with Chironomidae $(56 \%)$, Simuliidae $(11 \%)$, and Caenidae $(9 \%)$. With $4 \%$, insects formed a minor group in the interstitial biotope. Baetidae, large instars of Hydropsychidae, and to a lesser extent, Calopterygidae and Gomphidae were relatively well represented in the surface water, but did not occur in interstitial zone, whereas early instars of Trichoptera Hydropsychidae, Diptera Thaumaleidae and Psychodidae were recorded in low number, but only in the hyporheic zone. Diptera Ceratopogonidae, Heteroptera Corixidae, Coleoptera Dryopidae and Hydrophilidae, and Hydracarina occurred more frequently in the hyporheic biotope than in surface water. Oligochaeta and Nematodes were relatively common in interstitial water ( $11 \%$ and $10 \%$ respectively). Among Oligochaeta, Nais elinguis was only present in benthic habitat whereas Trichodrilus sp. and Enchytraeus sp. appeared to be permanent inhabitants of the hyporheal. Limnodrilus hoffmeisteri, Tubifex tubifex, Haplotaxis sp. and Paranais birsteini were collected from both habitats, but the highest population density of $P$. birsteini occurred in surface water.

There were only minor differences in the number of taxa collected in upstream and downstream sites within the study area (Table 2), and the fauna composition showed no significant difference between sites A and $\mathrm{C}$ for all periods. The interstitial fauna samples realized in the middle of the river channel (RB) did not differ significantly from the other hyporheos samples taken on the river banks. The between-group correspondence analysis shows the distribution of the study sites on the F1-F2 map (Fig. 3A). This map explains $73 \%$ of the variability contained in the data matrix, with $57 \%$ for the first axis. The first axis opposes the samples collected in each biotope, the hyporheic samples having negative scores on the F1 axis. Site B corresponds to an upwelling zone setting the site under the influence of the ground water table. The distinctive taxa of these site belong typically to the hypogean fauna: $\mathrm{Mi}$ crocharon sp. and Typhlocirolana sp. (Fig. 3B), which density significantly decreased downstream $(\mathrm{p}<0.05)$. Scores of the benthic samples are on the positive part of the F1 axis. These samples are characterized by a higher percentage of benthic fauna only occurring in surface water (Ephemeroptera Baetis, Cloeon and Caenis, Diptera Simuliidae, Oligochaeta Paranais). Within the hyporheic zone, the community heterogeneity, expressed on the second axis, reflects the heterogeneity of the abiotic conditions. Indeed, site $\mathrm{C}$, which is below the F1 axis, is characterized by taxa, generally occurring in poorly oxygenated biotope, like air breathing insects 
Table 2. Fauna list and relative abundance (\%) of the taxa at the three hyporheic study sites on the river banks (A, B, and C), at the hyporheic site in the river bed (RB), and in the benthic biotope (SR). $x=$ percentage less than 0.01 .

\begin{tabular}{|c|c|c|c|c|c|c|}
\hline Taxa & & $\mathbf{A}$ & B & $\mathbf{C}$ & $\mathbf{R B}$ & SR \\
\hline Nematoda & & 15 & 11 & 19 & 5 & 4 \\
\hline \multirow[t]{7}{*}{ Oligochaeta } & Tubifex tubifex (Muller, 1774) & 5 & 2 & 7 & 2 & 3 \\
\hline & Limnodrilus hoffmeisteri Claparède, 1862 & 0.3 & 0.2 & 2.2 & 3 & 1.3 \\
\hline & Paranais birsteini Sokolskaya, 1971 & $\mathrm{x}$ & $\mathrm{x}$ & 1 & 0.2 & 4 \\
\hline & Nais elinguis Muller, 1773 & & & & & 2 \\
\hline & Trichodrilus sp. & 10 & 10 & 3 & 1.2 & $\mathrm{x}$ \\
\hline & Haplotaxis sp. & & & 0.3 & 0.2 & $\mathrm{x}$ \\
\hline & Enchytraeus sp. & 0.2 & 1.4 & 2.2 & & $\mathrm{x}$ \\
\hline Gastropoda & Physidae & 1 & 1.3 & 3.4 & 0.6 & 1 \\
\hline \multirow[t]{3}{*}{ Cladocera } & Alona rectangula Sars, 1862 & 1 & 0.1 & 2 & 34 & 0.3 \\
\hline & Ceriodaphnia reticulata (Jurine, 1820) & 3 & 1 & 4 & 3 & 18 \\
\hline & Simocephalus exspinosus (Koch 1841) & 3 & 1 & 4 & 4 & 10 \\
\hline \multirow[t]{2}{*}{ Copepoda } & Acanthocyclops viridis viridis (Jurine, 1820) & 51 & 54 & 17 & 34 & 24 \\
\hline & Harpacticoidae & 1.4 & 9 & 0.1 & 0.3 & $\mathrm{x}$ \\
\hline \multirow[t]{5}{*}{ Ostracoda } & Heterocypris incongruens (Ramdohr, 1808) & 0.5 & 2 & 1 & 13 & 3 \\
\hline & Heterocypris salina (Brady, 1862) & 3 & 0.3 & 2 & 0.1 & 1.5 \\
\hline & Ilyocypris bradyi (Sars, 1890) & 1 & 0.1 & 1.5 & 0.2 & 0.4 \\
\hline & Herpetocypris brevicaudata (Kaufmann, 1900) & 0.6 & 0.3 & 0.2 & 0.2 & 1 \\
\hline & Pseudocandona pratensis (Hartwig, 1901) & 0.1 & & 4 & & \\
\hline \multirow[t]{2}{*}{ Isopoda } & Microcharon sp. & 2 & 3.2 & 0.1 & & \\
\hline & Typhlocirolana sp. & 1 & 1 & & 0.2 & \\
\hline Amphipoda & Echinogammarus (cf. rhipidiophorus) & & 0.1 & & & \\
\hline Syncarida & Bathynellidae & & 0.1 & & & \\
\hline Hydracarina & & 0.4 & 0.5 & 1 & 0.2 & $\mathrm{x}$ \\
\hline Collembola & & 1.2 & 2 & 7 & 0.3 & $\mathrm{x}$ \\
\hline \multirow[t]{3}{*}{ Ephemeroptera } & Caenis luctuosa (Burmeister, 1839) & 0.1 & 0.1 & 0.6 & $\mathrm{x}$ & 3 \\
\hline & Cleon cognatum Stephens, 1835 & & & & & 2 \\
\hline & Baetis pavidus Grandi, 1949 & & & & & 2.2 \\
\hline \multirow[t]{3}{*}{ Odonata } & Aeschnidae & & & & & $\mathrm{x}$ \\
\hline & Calopterygidae & & & & & 0.3 \\
\hline & Gomphidae & & & & & 0.1 \\
\hline \multirow[t]{2}{*}{ Trichoptera } & Hydropsychidae & & & & & 1 \\
\hline & Hydropsychidae (larvulae) & & & 3.6 & & \\
\hline \multirow[t]{2}{*}{ Heteroptera } & Corixidae & 0.3 & 0.1 & 0.6 & $\mathrm{x}$ & 1 \\
\hline & Gerridae & 0.1 & & 0.1 & & \\
\hline \multirow[t]{5}{*}{ Coleoptera } & Helophoridae & 0.4 & & & & 0.1 \\
\hline & Elmidae & $\mathrm{x}$ & & & & $\mathrm{x}$ \\
\hline & Dryopidae & & 0.6 & & & 0.2 \\
\hline & Hydrophilidae & $\mathrm{x}$ & & & & \\
\hline & Dytiscidae & & & 0.6 & & 0.1 \\
\hline \multirow[t]{7}{*}{ Diptera } & Thaumaleidae & & & 1 & & \\
\hline & Psychodidae & & & 0.1 & & \\
\hline & Stratiomyidae & & & 0.3 & & \\
\hline & Chironomidae & 1 & 0.4 & 2 & 1.3 & 17 \\
\hline & Ceratopogonidae & 0.3 & 0.4 & 13 & $\mathrm{x}$ & 0.2 \\
\hline & Simuliidae & 0.2 & & & $\mathrm{x}$ & 3 \\
\hline & Taxa number & 29 & 26 & 30 & 23 & 34 \\
\hline
\end{tabular}



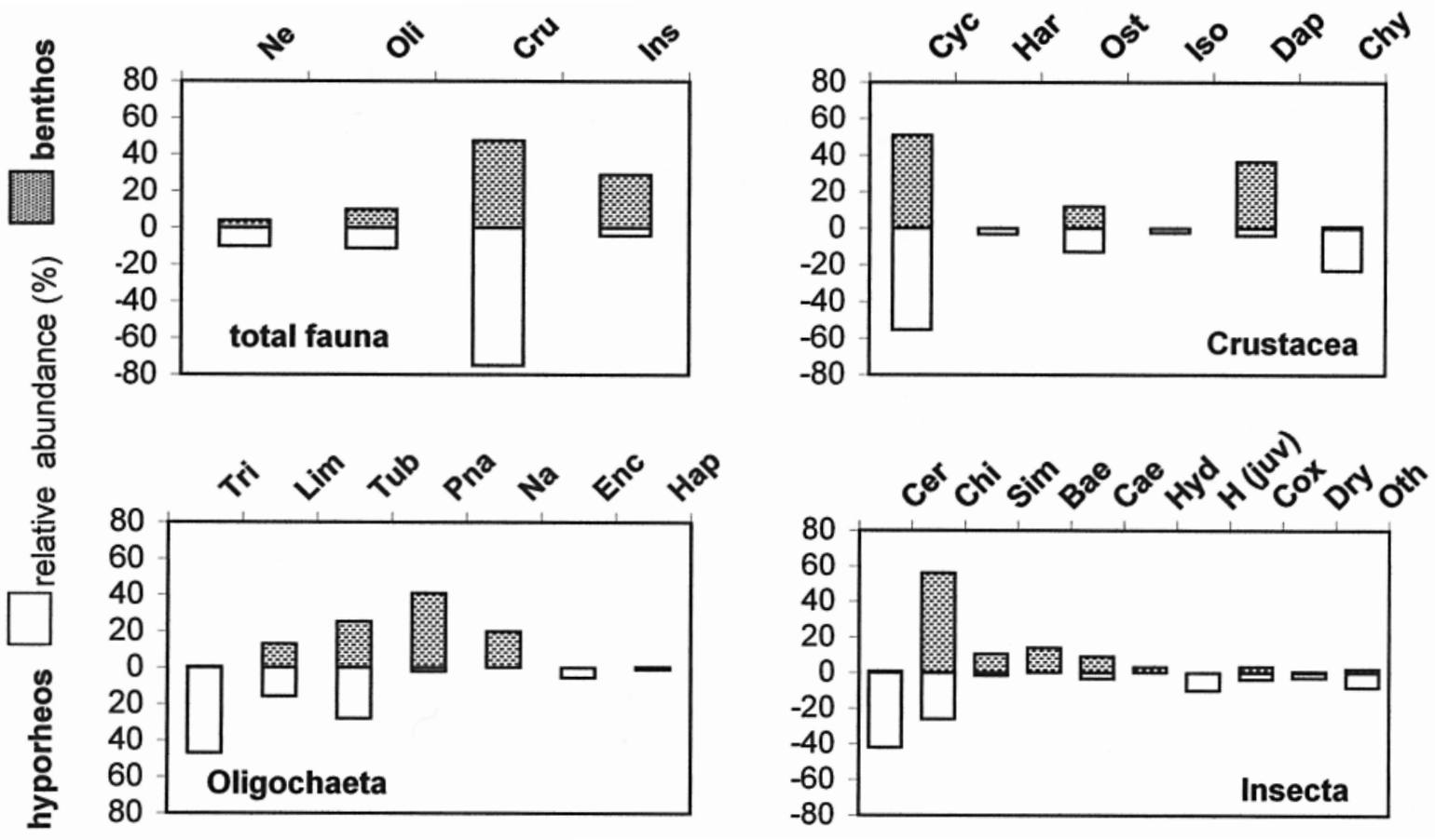

Fig. 2. Relative abundance of hyporheic fauna vs benthic fauna. Ne: Nematods ; Cru : Crustaceans ; Cyc : Cyclopoids ; Har : Harpacticoids ; Ost : Ostracoda ; Iso : Isopoda ; Dap : Daphniidae ; Chy: Chydoridae (Alona rectangula) ; Oli : Oligochaeta ; Tri : Trichodrilus sp.; Lim : Limnodrilus hoffmeisteri; Tub : T. tubifex ; Pna: Paranais birsteini ; Na : Nais elinguis ; Enc : Enchytraeus sp.; Hap : Haplotaxis sp. ; Ins : Insects ; Cer : Ceratopogonidae ; Chi: Chironomidae ; Sim : Simuliidae ; Bae : Baetidae ; Cae : Caenidae ; Hyd : Hydropsychidae ; H(juv) : young instars of Hydropsychidae ; Cox : Corixidae ; Dry : Dryopidae ; Oth : other Insects.

such as Collembola, Psychodidae, Stratiomyidae, burrowing taxa such as Caenidae or Ceratopogonidae, and some larvae of still water taxa such as Heteroptera Corixidae and Coleoptera Dytiscidae (Table 2). The decrease of the stygobite fauna suggests a heterogeneous distribution. Indeed, the sediment grain size, fine at site $\mathrm{C}$, seemed to influence these groups. Contrarily, densities of Limnodrilus hoffmeisteri, Ilyocypris bradyi, Heterocypris salina and Ceratopogonidae were higher at the downstream site. This fauna has to be related to the type of substrate observed at site $\mathrm{C}$, i.e. fine sediment filling the interstices (Table 1) and reducing gas exchanges between the interstitial and the surface biotopes. Site B, situated above the first axis, is richer in taxa preferring coarser substratum enhancing fast water circulation. Thus, the second axis can be considered as a gradient of very local conditions (sediment porosity, water origin) highly correlated with the type of biotope (i.e. hyporheic or benthic).

\section{Impact of dam water releases on the downstream hyporheic and benthic fauna}

Neither hyporheic taxa richness nor diversity indices fluctuated significantly between sites for any sampling period. For Ceratopogonidae $(\mathrm{F}=4.80, \mathrm{p}<0.05)$ and $L$. hoffmeisteri $(\mathrm{F}=5.11, \mathrm{p}<0.05)$ the difference was significant between sites $\mathrm{A}$ and $\mathrm{C}$ during release periods, as well as for I. bradyi $(\mathrm{F}=22.23, \mathrm{p}<0.042)$ and $H$. salina $(\mathrm{F}=16.56, \mathrm{p}<0.055)$ after the release period (Fig. 4). At site B, Harpacticidae had their highest density during the dry period, and Ostracoda Heterocypris incongruens were abundant after release period. The dam construction enhanced taxa richness and Shannon's values downstream (Fig. 5). This was due to the occurrence of Coleoptera (Helophoridae, Hydrophilidae and Elmidae) at site A, to Diptera families (Thaumaleidae, Psychodidae and Stratiomyidae) and early instars of Trichoptera Hydropsychidae at site C. Ho- 


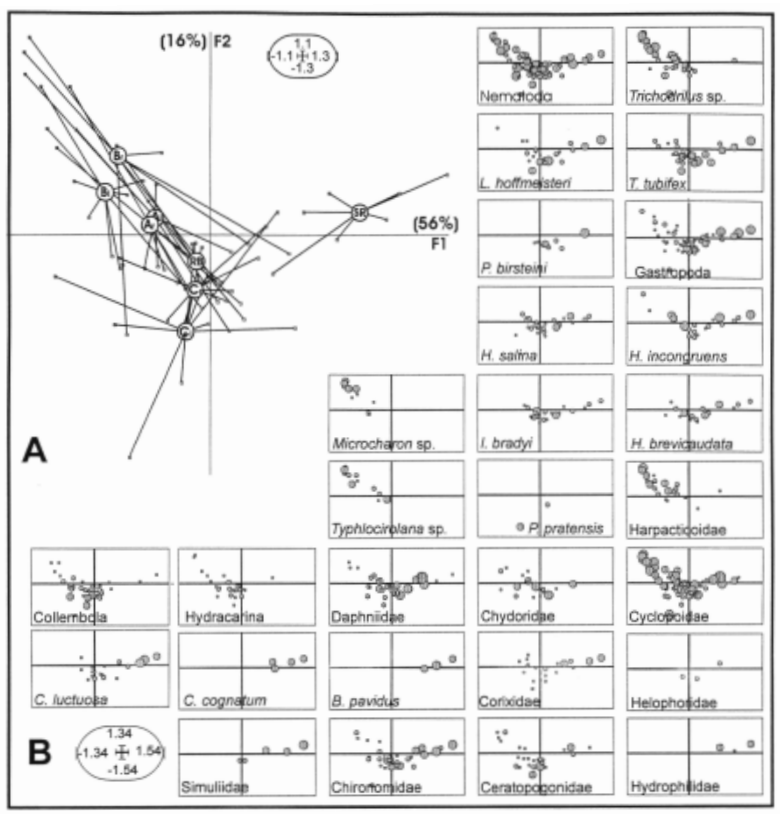

Fig. 3. Between-group correspondence analysis of fauna sampled within sites $A, B, C$, subterranean river bed (RB), and benthic biotope (SR) (r: right bank; l: left bank).

wever, diversity analyses did not reveal a significant change before and after release when all samples were considered. The only exception was site $\mathrm{C}$, where diversity values slightly increased (Fig. 5B). Significant difference in average densities were found between periods for most taxa (Fig. 4). The densities of Trichodrilus sp. $(\mathrm{F}=3.39, \mathrm{p}<0.05)$, Copepods Acanthocyclops sp. $(\mathrm{F}=3.73, \mathrm{p}<0.024)$ and Harpacticoides $(\mathrm{F}=3.11$, $\mathrm{p}<0.044)$, and Isopods: Typhlocirolana $\mathrm{sp} .(\mathrm{F}=3.06$, $\mathrm{p}<0.046)$ and Microcharon sp. $(\mathrm{F}=6.38, \mathrm{p}<0.002)$, were drastically reduced after dam water release $(p<0.05)$ with a fall of about 80 to $97 \%$. Densities of Tubificidae and Ceratopogonidae slightly increased, but not significantly. These families became more predominant during the release periods than before. These groups are considered to be more pollution tolerant. Densities of Heterocypris incongruens, Heterocypris salina $(\mathrm{F}=3.15, \mathrm{p}<0.042)$ and Daphniidae $(\mathrm{F}=2.71$, $\mathrm{p}<0.053)$ were lower before release period, but their abundances increased during release periods and the highest density has been recorded after the release periods $(\mathrm{p}<0.053)$. Their colonization had been established under low flow conditions. Ilyocypris bradyi $(\mathrm{F}=$ 4.71, $\mathrm{p}<0.05)$ and Chydoridae $(\mathrm{F}=3.09$, $\mathrm{p}<0.034)$ (absent before releases) occurred during dam water releases and their densities were the highest after the release period. Nematodes, Chironomidae and Herpeto- cypris brevicaudata seemed to be unaffected by water release.

In the figure 6A, the first axis (29\% of total variation) shows an hydraulic gradient. Samples from the dry season are displayed farthest on the right of the axis with distinctive taxa (hypogean fauna) such as Isopods, Copepods and Oligochaeta Trichodrilus (Fig. $6 \mathrm{~B})$. Samples from water release period stand farthest on the negative side of this axis with abundance of epigean Oligochaeta, Chironomidae, Simuliidae and $\mathrm{Ce}$ ratopogonidae. After release samples have an intermediate position, thus indicating a structure based on the recolonization by stagnant water organisms (Cladocera). The second axis (19\% of total variation) is related to the rainy season at site $\mathrm{C}$ with Trichodrilus sp., $\mathrm{Cy}-$ clopoidae and Pseudocandona pratensis. This later taxa occurred only during the rainy season. Microcharon sp. and Typhlocirolana sp. were more abundant during the dry season (Fig. 6B). Limnodrilus hoffmeisteri, Tubifex tubifex, Ostracods (except Pseudocandona pratensis) and Ceratopogonidae were found only during release periods. Cladocera occurred during release and were more abundant after release periods.

\section{Discussion}

\section{Composition and spatial distribution of the fauna}

Compared to the taxa richness $($ mean $=22)$ observed by Gagneur and Chaoui-Boudghane (1991) in their hyporheic fauna study in the Tafna basin headwaters (sampled with the Karaman-Chappuis method) more taxa have been recorded in the present study (mean richness $=28$ ). This difference can be attributed to sampling technique and volume of pumped water. According to Gibert et al. (1981) and Mauclaire et al. (1998), the pumping method used in our study should provide a better representation of the communities.

Although their taxonomic richness and their diversity were similar, the three hyporheic sites are characterized by very different interstitial assemblages. In the upstream site, hypogean species were collected and the density of the hyporheos was higher than at the downstream site, especially concerning Trichodrilus sp., Cyclopoidae, Harpacticoidae and Ostracoda Heterocypris incongruens. At the downstream site stygobite taxa were lacking, but the relative abundances of Ceratopogonidae and Limnodrilus hoffmeisteri were the highest. This distribution can be attributed (i) to habitat differences, (ii) to response to changes in sediment size and underflow dynamic, as already pointed out by Rouch (1988) for interstitial Crustaceans, (iii) and to 

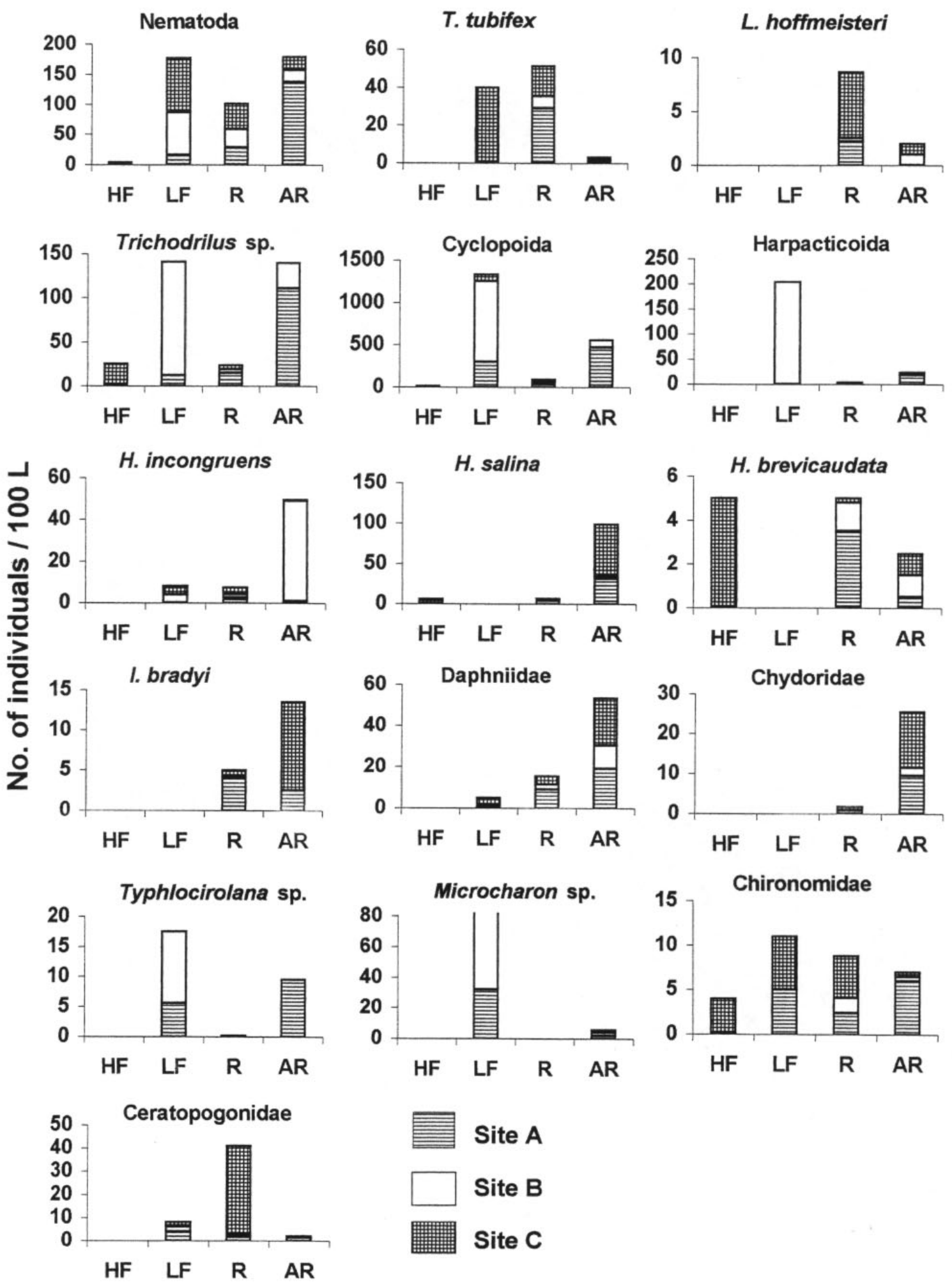

Site A

Site B

Site C

Fig. 4. Spatial and temporal variations in the density of the most common taxa in the hyporheic zone. High Flow (HF), Low Flow (LF), Release (R) and After Release (AR) periods. 

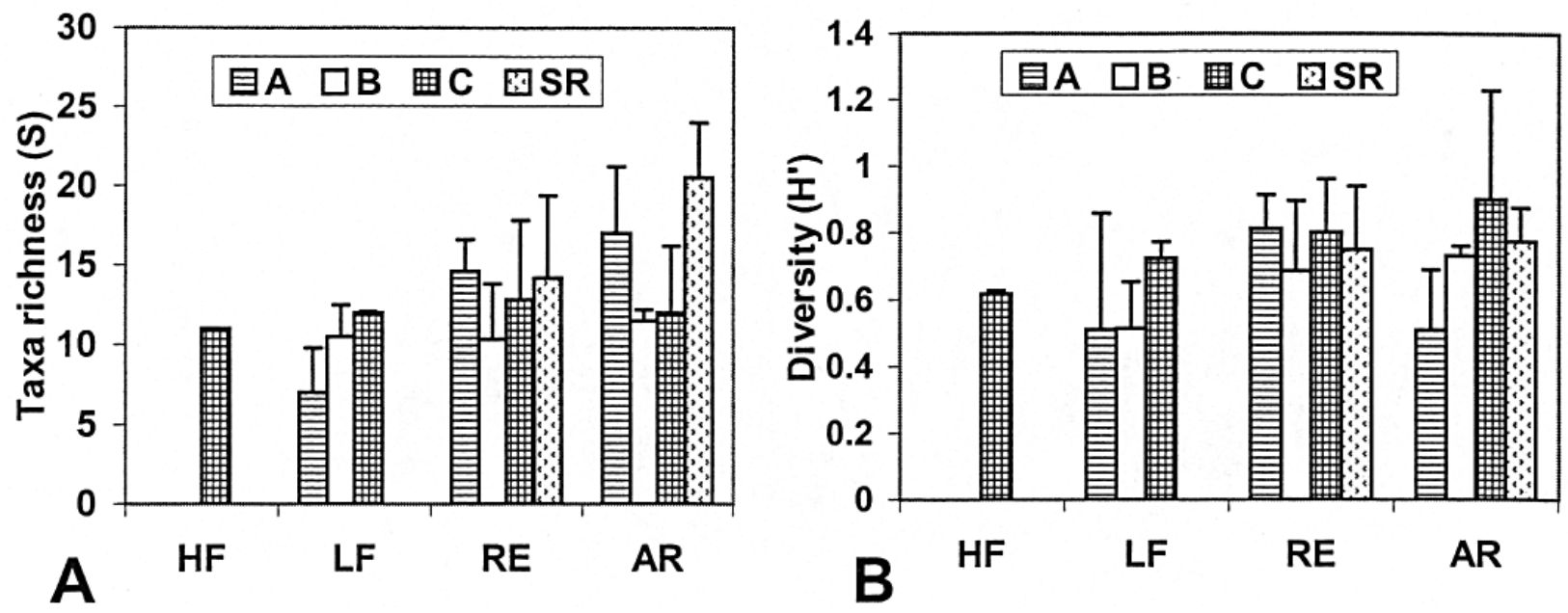

Fig. 5. Diversity at the three hyporheic sites (A, B and C) and in benthic zone (SR) at the four periods (abbreviations as in Fig. 4): A: Mean taxonomic richness $(\mathrm{S})+\mathrm{SD}$. B: Mean diversity $\left(\mathrm{H}^{\prime}\right)+\mathrm{SD}$.

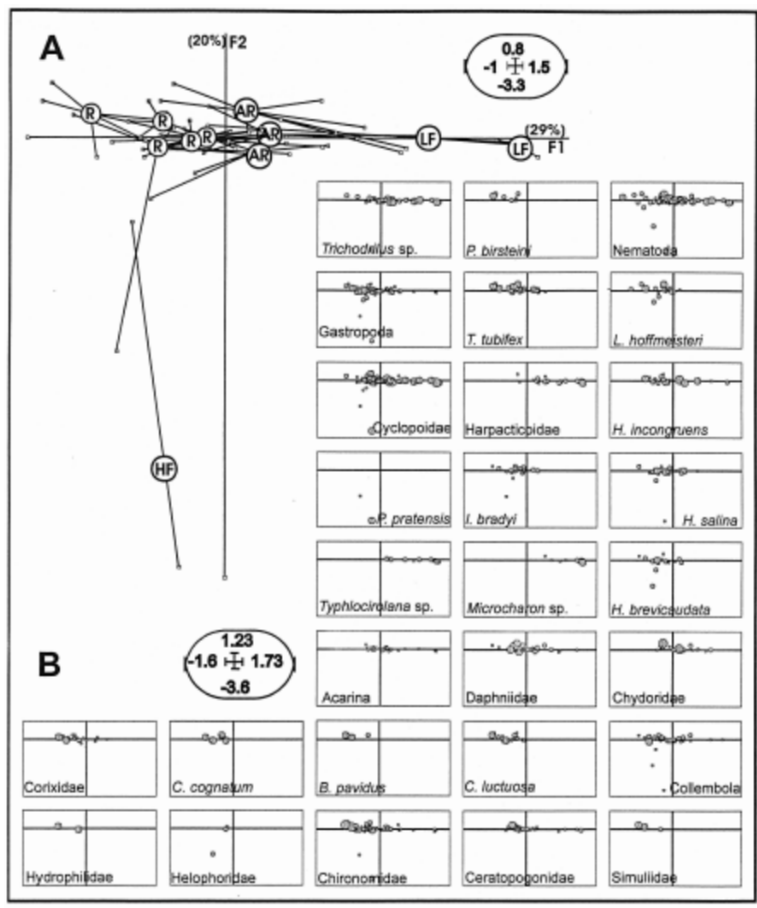

Fig. 6. Between-group correspondence analysis of fauna sampled during the four hydrological periods. (abbreviations as in Fig. 4). increasing hypoxy and pollution. Indeed, at site $\mathrm{C}$ the overall decrease in invertebrate abundances may be due to hypoxic conditions induced by the high percentage of fine sediments which clog the interstices and limit oxygenation, as reported by Strayer et al. (1997). The fauna in the interstitial biotope appears to be highly dependent on the sediment porosity, and therefore on sediment composition resulting from the flow regime (Angelier 1962). The distribution and abundance of stygobite taxa could be used for assessing the impact levels in this lowland plain : Typhlocirolana and Microcharon are common hypogean taxa at this site, but their low abundance can partly be explained by the relative low sampling depth (Berrady et al. 2000), and by their sensitivity to abiotic conditions (Mosslacher 2000) and to pollution (Boutin 1984). Strict phreatobites such as Echinogammarus cf. rhipidiophorus are slightly represented, or never occur (e.g., Amphipods Salentinellidae). This last family generally occurs in deep sediment (Dole-Olivier \& Marmonier 1992). Bathynellidae which predominate under hypoxic condition in the hyporheic zone of a Sonoran desert stream (Boulton \& Stanley 1995) are rare in the Tafna River. The low percentage of stygobite taxa can be due to the vertical hydraulic gradient, generally negative (Marmonier \& Creuzé des Châteliers 1991), and may indicate a low stability of the study site (Mermillod-Blondin et al. 2000). Indeed, the study reach is characterized by downwelling water movements, particularly at downstream site, and is exposed to severe man induced pollution (Taleb et al. in press). However, most of other hyporheic taxa appear to be tolerant to pollution, 
such as Crustacean Cyclopoidae and Chydoridae, or Oligochaeta Limnodrilus hoffmeisteri and Tubifex tubifex. These last two species belong to a group of organisms known as pollution-resistant (Giani 1984), as generally are Dipterans, notably Ceratopogonidae and Chironomidae.

The comparison between hyporheic and surface fauna shows a high density of insects in surface habitats, especially Chironomidae, Baetidae, and Caenidae, and high density of Oligochaeta (Naididae). The assemblage composition may be a consequence of extreme conditions occurring in lowland semi-arid streams (Gagneur \& Thomas 1988; Lounaci et al. 2000), and of chronic pollution (Gibert et al. 1998) as that observed in the river downstream of the Maghnia locality. Indeed, Oligochaeta Naididae respond to organic pollution by increasing their abundance (Learner et al. 1978). The epigean taxa, like insects, occurring within the sediments are essentially young instars (e.g. Hydropsychidae larvulae). The exchanges of fauna between superficial and interstitial biotopes follow hydraulic patterns but also life cycles, and therefore, the faunal composition of the hyporheos should be considered over a year cycle (Rouch 1982).

\section{Role of the hyporheic zone in temporary river functioning}

The increase of epigean taxa in the hyporheic habitat reflects the intensity of disturbances (Dole-Olivier \& Marmonier 1992), and the high similarity recorded between hyporheic and benthic biotopes suggest that surface organisms migrate into the hyporheic zone (e.g. Cyclopoidae, Tubificidae and Chironomidae). However, this later family, which is considered in other studies as a major component of hyporheic insects assemblages (Williams 1984, 1989, McElravy \& Resh 1991) is less represented here in the hyporheos than Ceratopogonidae. Numerous epigean taxa enter the sediment when the flow is sufficient, which could be interpreted as an evidence of the shelter role played by the hyporheic zone. This occurs during dam water releases because organisms have the ability to avoid surface pollution by seeking for better conditions in the sediment where less polluted groundwater rise near the river bed (site B). Migration into the sediment may be active or passive, enhanced by increasing porosity of the sediment, and thus determining more diversified assemblages. However, according to Gibert et al. (1981), these assemblages may not be temporally stable. This migration is not observed in the study area during the drying of the Tafna bed. This confirms the results already obtained by Gagneur \& Chaoui-Boud- ghane (1991) who reported that few benthic species over-summered in the hyporheic zone during drying in the upper Tafna basin. Del Rosario \& Resh (2000) also showed that the hyporheic zone offered no shelter against drying for insect in a Californian stream. Finally, exchanges between benthos and hyporheos take place in the functioning as a natural process following the water flow exchanges between superficial runoff and underflow, mainly during high flow periods when sediment porosity is high. Small, burying, and juvenile organisms colonize the interstitial biotope in order to avoid the current, and maybe predators like Odonata. When the flow become reduced naturally (dry season), or artificially (water retention by a dam), fine particles are deposed and clog the interstices. When the river bed get dry, cobbles are cemented and the hyporheic zone is isolated from the atmosphere, thus stopping aeration and oxygen diffusion towards interstitial water. This leads to reduction process in the hyporheic water when it is organically polluted (Taleb et al. in press). Interstitial taxa are then exposed to harsh conditions and only the most tolerant one can survive in such biotopes. When the topography or seasonal water table rising allow groundwater upwelling process, the polluted water can be in some way diluted (site B) and more stygobyte taxa are collected (e.g. Microcharon).

\section{Reservoir operating and response of invertebrate assemblages}

It clearly appears that the distribution and abundance of specific taxa should be considered as a response to the new environment created by the HammamBoughrara reservoir. Reservoir water releases are known to cause short-term changes in abiotic conditions in the Tafna river (Taleb et al. in press). The reduced flushing effect of the spates, which rejuvenated the stream bed by eliminating the fine particles, deposed within sediments during low flow, did not occur anymore since the dam was built. Moreover, this recently created reservoir collects and stores industrial and urban waste water from the Maghnia locality. The release for irrigation supply of highly organically polluted water during the dry period leads to enhance water seeping into the sediment in deeper zones (down to $50 \mathrm{~cm}$ ), and therefore to enrich the interstitial biotope with organic matter. The later habitat becomes hypoxic, much more markedly than in surface water (Table 1).

Our investigations show that the reservoir water has a significant effect on the hyporheic assemblages of the three sites. Changes in fauna composition can be 
related to changes in water quality and hydraulic conditions. This is obvious from comparisons of fauna assemblages before and after releases, all invertebrate groups being unequally affected. Species richness and diversity do not vary greatly, possibly reflecting the rapidity with which most hyporheic sensitive taxa, such as Oligochaeta Trichodrilus sp., Copepods, Isopods, Amphipods, and Syncarids, are replaced. Crustaceans are absent from impacted sites. Simon \& Buikema (1997) and Wood et al. (2002) found that Amphipods and Isopods were absent from heavily polluted subterranean water in Banners Corner Cave (Virginia, USA), demonstrating the vulnerability of these organisms to pollution and their value as indicator organisms in subterranean environments (Wood et al. 2002). The other taxa seem less affected. It may signify that these species are physiologically more tolerant to water pollution.

The occurrence of planktonic taxa in surface running water may be explained by the water origin. Cladocera normally living in stagnant and low flow water, came probably from the Hammam-Boughrara reservoir and their number increased downstream, after dam releases stop.

\section{Conclusion}

This study carried out on a small river reach shows that the weak and slow water movements in the interstitial biotope force to work on a smaller scale than in the surface biotope, where the homogeneity is greater, due to faster water movements. The hyporheic biotope appears to be a set of mosaic of microcosms depending on very localized and fluctuating conditions, such as sediment grain size, clogging, up- and downwelling zones. Each of these parameters determines a type of interstitial community, selecting adapted taxa, and eliminating the less eurytopic ones.

The higher taxonomic richness during and after reservoir releases is related to the installation and diversification of pollution resistant assemblages whose development is bound to the sediment enrichment of organic matter. The hydrological conditions in the river, particularly the alternation of high and low discharges, appear to affect the hyporheos more than the benthic communities. The benthic macroinvertebrates enter actively the hyporheic zone when flow enhance the porosity of the sediment and also to avoid superficial pollution. In contrast, when the river dries, the invertebrates enter passively the hyporheic zone, following the water seeping, and avoiding the harsh surface conditions (high temperature and mineralization, pre- dation). The stability concept of the interstitial assemblages, largely verified in unpolluted or slightly polluted streams, cannot be applied in the case of heavily polluted streams exposed to high flow amplitude. When flow is reduced, limited or absent, altering water exchanges with the surface water, the mineralization of the organic matter inside the interstitial biotope induces an eutrophication that cannot be adapted to all the organisms which occur here during high water period. Thus, hyporheic assemblages fluctuate more than benthic assemblages, following the greater physicochemical fluctuations measured in the hyporheic biotope (Taleb et al. 2004). Additional studies of heavily polluted North African wadis should be conducted in order to better understand the mineralization processes in the interstitial zone and to evaluate the extend and impact of the eutrophication, not only on invertebrates but also on microbiological assemblages.

\section{Acknowledgments}

We are greatly indebted to all the specialists who provided invaluable help by identifying our material: P. Marmonier (Ostracods), N. Giani (Oligochaeta), C. Boutin (Amphipods, Isopods), F. Azemar (Cladocera and Copepods) and A. Thomas (Ephemeroptera). We would like also to thank heartily Abdou who helped with the field. Many thanks to S. Brosse and to anonymous referees who made useful comments on an earlier version of this paper.

\section{References}

Angelier E. 1962. - Remarques sur la répartition de la faune dans le milieu interstitiel hyporhéique. Zool. Anz., 168, 351-356.

Belaidi-Aliane N. 1992.- Etude de la salinité dans le bassin versant de la Tafna et son influence sur quelques organismes benthiques. Magister Thesis, University of Tlemcen (Algeria), $64 \mathrm{p}$.

Bendiouis C. 1991.- Contribution à l'étude de la faune hypogée d'Afrique du Nord (Milieux hyporhéique et phréatique). Magister Thesis, University of Tlemcen (Algeria), 109 p.

Berrady I., Essafi K. \& Mathieu J. 2000.- Comparative physico-chimical and faunal studies of two thermal spring brooks near Sidi Harazem (Morocco). Ann. Limnol.-Int. J. Lim., 36, 261- 274.

Bou C. 1974.- Les méthodes de récolte dans les eaux souterraines interstitielles. Ann. Speleol., 29, 611-619.

Bou C. \& Rouch R. 1967.- Un nouveau champs de recherche sur la faune aquatique souterraine. C.R. Acad. Sc. Paris, 265, 369-370.

Boulton A.J. \& Stanley E.H. 1995.- Hyporheic processes during flooding and drying in a Sonoran Desert stream. II Faunal dynamics. Arch. Hydrobiol., 134, 27-52.

Boutin C. 1984.- Sensibilité à la pollution et répartition de quelques espèces de crustacés phréatobies à Marrakech. Mém. Biospéol., $11,55-64$.

Chafiq M., Gibert J., Marmonier P., Dole-Olivier M.J. \& Juget J. 1992.- Spring ecotone and gradient study of interstitial fauna along two floodplain tributaries of the river Rhône, France. Regul. Riv., 7, 103- 115.

Claret C., Marmonier P., Boissier J.M., Fontvielle D. \& Blanc P. 1997.- Nutrient transfer between parafluvial interstitial water and river : influence of gravel bar heterogeneity. Freshwater Biol., 37, $657-670$ 
Del Rosario R.B. \& Resh V.H. 2000.- Invertebrates in intermittent and perennial streams: is the hyporheic zone a refuge from drying ? $J$. N. Am. Benthol. Soc., 19, 680- 696.

Dole M.J. 1985.- Le domaine aquatique souterrain de la plaine alluviale du Rhône à l'est de Lyon. 2. Structure verticale des peuplements des niveaux supérieurs de la nappe. Stygologia, 1, 270291.

Dole-Olivier M.J. \& Marmonier P. 1992.- Patch distribution of interstitial communities: prevailing factors. Freshwater Biol., 27, 177-191.

Dole-Olivier M.J., Marmonier P. \& Beffy J.L. 1997.- Response of invertebrates to lotic disturbance: is the hyporheic zone a patchy refugium? Freshwater Biol., 37, 257-276.

Gagneur J \& Chaoui-Boudghane C. 1991.- Sur le rôle du milieu hyporhéique pendant l'assèchement des oueds de l'ouest Algérien. Stygologia, 6, 77-89.

Gagneur J. \& Thomas A.G.B. 1988.- Contribution à la connaissance des Ephéméroptères d'Algérie, I. Répartition et écologie ( $1^{\text {ire }}$ partie ) (Insecta, Ephemeroptera). Bull. Soc. Hist. Nat., Toulouse, 124, 213-223.

Giani N. 1984. Le Riou Mort, affluent du Lot, pollué par les métaux lourds. IV. Etude des Oligochètes. Ann. Limnol.-Int. J. Lim., 20, 167-181.

Gibert J., Ginet R., Mathieu J. \& Reygrobellet J.L. 1981.- Structure et fonctionnement des écosystèmes du Haut-Rhône Français; IX Analyse des peuplements de deux stations phréatiques alimentant des bras morts. Int. J. Speleol., 11, 141-158.

Gibert J., Marmonier P. \& Plénet S. 1998.- Efficiency of bank filtration: biotic processes. Verh. Internat. Verein. Limnol., 26, 1027 1031.

Griffith M.B. \& Perry S.A. 1993.- The distribution of macroinvertebrates in the hyporheic zone of two small Appalachian Headwater streams. Arch. Hydrobiol., 126, 373-384.

Grimm N.B. \& Fisher S.G. 1984.- Exchange between interstitial and surface water: Implications for stream metabolism and nutrient cycling. Hydrobiologia, 11, 219-228.

Learner M.A., Lochhead G. \& Hughes B.D. 1978.- A review of the biology of British Naididae (Oligochaeta) with emphasis on the lotic environment. Freshwater Biol., 8, 357- 375.

Lounaci A., Brosse S., Thomas A. \& Lek S. 2000.- Abundance, diversity and community structure of macroinvertebrates in Algerian stream: the Sébaou wadi. Ann. Limnol.-Int. J. Lim., 36, 123133.

Maridet L., Wasson J.G. \& Philippe M. 1992.- Vertical distribution of fauna in the bed sediment of three running water sites: Influence of physical and trophic factors. Regul. River, 7, 45- 55.

Marmonier P. \& Creuzé des Châteliers M. 1991.- Effects of spates on interstitial assemblages of the Rhône River. Importance of spatial heterogeneity. Hydrobiologia, 210, 243- 251.

Marmonier P. \& Dole M.J. 1986.- Les Amphipodes des sédiments d'un bras court-circuité du Rhône. Logique de répartition et réaction aux crues. Rev. Sci. Eau, 5, 461-486.
Mauclaire L., Marmonier P \& Gibert J. 1998.- Sampling water and sediment in interstitial habitats: a comparison of coring and pumping techniques. Arch. Hydrobiol., 142, 111-123.

McElravy E.P. \& Resh V.H. 1991.- Distribution and seasonal occurrence of the hyporheic fauna in northern California stream. Hydrobiologia, 220, 233-246.

Mermillod-Blondin F., Creuzé des Châteliers M., Marmonier P. \& Dole-Olivier M.J. 2000.- Distribution of solutes, microbes and invertebrates in river sediment along a riffle-pool-riffle sequence. Freshwater Biol., 44, 255-269.

Mosslacher F. 2000.- Sensitivity of groundwater and surface water crustaceans to chemical pollutants and hypoxia: implications for pollution management. Arch. Hydrobiol., 149, 51-66.

Orghidan T. 1959.- Ein neuer Lebensraum des unterirdischen Wassers: Der hyporheische Biotop. Arch. Hydrobiol., 55, 392-414.

Poole W.C. \& Stewart K.W. 1976.- The vertical distribution of macrobenthos within the substratum of the Brozo River, Texas. $H y$ drobiologia, 50, 151-160.

Rouch R. 1982.- Le système karstique du Baget.XII. La communauté des Harpacticides. Sur l'interdépendance des nomocénoses épigée et hypogée. Ann. Limnol.-Int. J. Lim., 18, 41-54.

Rouch R. 1988.- Sur la répartition spatiale des crustacés dans le sous-écoulement d'un ruisseau des Pyrénées. Ann. Limnol.-Int. J. Lim., 24, 213- 234.

Rouch R. 1995.- Peuplement des crustacés dans la zone hyporhéique d'un ruisseau des Pyrénées . Ann. Limnol.-Int. J. Lim., 31, 9-28.

Simon K.S. \& Buikema A.L. 1997.- Effect of organic pollution on an Appalachian cave: Changes in macroinvertebrate population and food supplies. Amer. Midl. Nat., 138, 387-401.

Strayer DL., May SE., Nielsen P., Wollheim W. \& Hausam S. 1997.Oxygen, organic matter, and sediment granulometry as controls on hyporheic animal communities. Arch. Hydrobiol., 140, 131144.

Taleb A., Belaidi N. \& Gagneur J. (in press). - Water quality before and after dam building on a heavily polluted river in semi-arid Algeria. River Res. Appl.,

Thioulouse J., Chessel D., Dolédec S. \& Olivier J.M. 1997.- ADE-4 : a multivariate analysis and graphical display software. Stat. Comput., 7, 75-83.

Williams D.D. 1984.- Hyporheic zone as a habitat for aquatic insects and associated arthropods. Pages 430- 455 in Resh V.H. \& Rosenberg D.M. (eds.). The ecology of Aquatics Insects. Praeger Publishers, New York.

Williams D.D. 1989.- Towards a biological and chemical definition of the hyporheic zone in two Canadian rivers. Freshwater Biol., 22, 189-208.

Wood P.J., Gunn J. \& Perkins J. 2002.- The impact of pollution on aquatic invertebrates within a subterranean ecosystem -out of sight out of mind. Arch. Hydrobiol. 155, 223- 237. 